\title{
Arylation of Racemic Secondary Benzylic Electrophiles by Nickel Catalysis
}

Metal-Catalyzed

Asymmetric

Synthesis and

Stereoselective

Reactions

\section{Key words}

nickel

Negishi crosscoupling

enantioconvergency

1,1-diarylalkanes<smiles>[R]C(O)[Al]</smiles>

$( \pm)-1$
1. $\mathrm{MsCl}, \mathrm{Et}_{3} \mathrm{~N}$

2. $\mathrm{Ar}^{2} \mathrm{Znl}$ (1.7 equiv), $\mathrm{NiBr}_{2}$.diglyme (9 mol\%) $(S, S)-\mathrm{L}$ (13 mol\%), Lil (4 equiv)

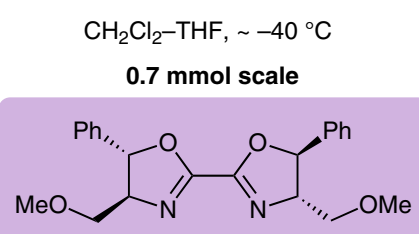

$(S, S)-\mathbf{L}$<smiles>[2H]C([Mg])[AlH2]</smiles>

44 examples up to $96 \%$ yield up to $95 \%$ ee
Selected examples:<smiles>CCC(c1ccccc1)c1ccc(OC)cc1</smiles>

$92 \%$ yield $94 \%$ ee<smiles>CC[C@H](c1ccc(OC)cc1)c1ccc(C(F)(F)F)cc1</smiles>

$94 \%$ ee<smiles>CCC(c1ccc(F)cc1)c1ccc(OC)cc1</smiles><smiles>CCC(c1ccc(OC)cc1)c1ccc2c(c1)OCO2</smiles><smiles>COc1ccc(C(C)c2cccc(N(C)O)c2)cc1</smiles>

$88 \%$ yield $92 \%$ ee<smiles>CC[C@H](c1ccc(OC)cc1)c1ccc2c(ccn2C(=O)OCc2ccccc2)c1</smiles><smiles>CCCCC(c1ccc(OC)cc1)c1ccoc1</smiles>

$88 \%$ yield $93 \%$ ee<smiles>CC(C)(C)OC(=O)CC[C@H](c1ccccc1)c1ccc(Cl)c(Cl)c1</smiles>

using $(R, R)-\mathbf{L}$
Significance: The 1,1-diarylalkane motif is found in a number of the top-selling pharmaceuticals. Therefore, the development of stereoselective methods to access this motif is a worthwhile pursuit. The authors report a two-step stereoconvergent synthesis of 1,1-diarylalkanes starting from racemic benzylic alcohols, which proceeds in excellent yields and with excellent enantioselectivities.

SYNFACTS Contributors: Mark Lautens, Christine M. Le Synfacts 2014, 10(1), 0043 Published online: 13.12.2013 Dol: 10.1055/s-0033-1340452; Reg-No.: L16213SF
Comment: A previous report by the same group disclosed a nickel-catalyzed enantioconvergent Negishi arylation of propargylic carbonates that was not applicable to the use of racemic benzylic carbonates (J. Am. Chem. Soc. 2012, 134, 2966). The current method generates a benzylic mesylate in situ. The authors propose that the lithium iodide additive transforms the mesylate into an alkyl iodide, which can then participate in the Negishi cross-coupling. 